\title{
16. TRACE ELEMENT DETERMINATIONS COMPARED WITH X-RAY DIFFRACTION RESULTS OF BROWN CLAY IN THE CENTRAL PACIFIC
}

\author{
Anthony C. Pimm, Scripps Institution of Oceanography, La Jolla, California
}

\section{INTRODUCTION}

Prior to DSDP Leg 17, no sites drilled in the central Pacific had continuously cored a thick section of pelagic brown clay. On Leg 6 several sites were drilled through brown clay, but poor recovery due to drilling difficulties, widely spaced cores, and a generally thin sediment cover over much of the area all contributed to a very limited amount of clay available for study. However, a preliminary attempt was made (Pimm, 1971) to identify the origins of the clay by examining the trace element and X-ray diffraction data.

On Leg 17 Site 164 situated at $13^{\circ} 12.14^{\prime} \mathrm{N}$, $161^{\circ} 30.98^{\prime} \mathrm{W}$ in a water depth of 5499 meters had a relatively thick brown clay section which was almost continuously cored (see Site Report) over a total length of about 250 meters. Unfortunately, once again drilling difficulties in chert-bearing clays contributed to a low recovery $(30 \%)$ and badly disturbed clay material. The shipboard party recognized two main lithologic units in the clay section as follows:

Unit 1: Zeolitic brown clay with abundant Radiolaria and radiolarian ooze with some porcelanitic chert in the lower part of the section-Cores 1 to 6 , interval 28 to 84 meters, ranging in age from Miocene to early Eocene.

Unit 2: Zeolitic brown clay and chert-Cores 7 to 26, interval 84 to 256 meters, ranging in age from late Cretaceous to early Cretaceous (Barremian to Albian).

Three other sites $(168,169,170)$ drilled on Leg 17 recovered only a few cores each of brown clay, and all had an extremely low percentage recovery.

\section{METHODS}

Samples were taken for atomic absorption analysis from Cores 1 through 22 from Site 164, but only eight other samples were taken from the remaining sites which recovered brown clay.

Equipment: Analyses were made with a Perkin-Elmer 303 Atomic Absorption Spectrophotometer using their Concentration Readout DCRI as a recording device. For $\mathrm{Mn}, \mathrm{Ni}$, and $\mathrm{Cr}$ an air acetylene flame was used with the standard burner head (303-0023); for V and Ti a nitrous oxide-acetylene flame was used with the nitrous oxide burner head (303-0195). Suggested Perkin-Elmer standard conditions and instrument settings were followed.

Sample Preparation: Between 0.2 and $1 \mathrm{~g}$ of sample was weighed, placed in a Teflon decomposition vessel, and wetted with $\sim 1 \mathrm{ml}$ distilled water. Five $\mathrm{ml}$ of $\mathrm{HF}$ was then added and the vessel covered and placed in a steam bath for 1 day. The cover was then removed, and the sample was left in the steam bath until dry. It was then wetted with $2 \mathrm{ml}$ distilled water, $2 \mathrm{ml} \mathrm{HC1}, 2 \mathrm{ml} \mathrm{HNO}_{3}$, and transferred to a flask. The $\sim 25 \mathrm{ml}$ of solution in the flask was then boiled for 10 minutes to facilitate dissolution, allowed to cool, transferred to volumetric ware, and diluted to 50 or $100 \mathrm{ml}$ and mixed. The solution was then stored in a polyethylene bottle. Standards were prepared from commercial 1000 ppm solutions to the following concentrations:

$$
\begin{aligned}
& \text { Mn } 2,4,10,20 \mathrm{ppm} \\
& \text { Cr } 0.5,1,1.5,2 \mathrm{ppm} \\
& \text { Ni } 1.5,3,10 \mathrm{ppm} \\
& \text { Ti } 10,20,30,40,100 \mathrm{ppm} \\
& \text { V } 1,2.5,5,10 \mathrm{ppm}
\end{aligned}
$$

Samples were first compared with standard solutions and then randomly checked using the method of additions. The latter procedure was included to check for possible interference effects. When necessary, samples were diluted with distilled water.

Error: The standard deviation was in all cases less then $10 \%$ of experimental mean except for $\mathrm{Cr}$ concentrations below $30 \mathrm{ppm}$ and $\mathrm{V}$ concentrations below $50 \mathrm{ppm}$. In these two cases the standard deviation was less than $20 \%$ of the mean.

X-ray diffraction: The DSDP laboratory at UC Riverside provided the X-ray data used in this chapter. A complete listing of this data is given elsewhere in this volume. A few additional X-ray analyses (semiquantitative only) were made by this author.

\section{RESULTS AND DISCUSSION}

The results of the atomic absorption analyses are given in Table 1.

\section{Site 164}

The Mn content is rather variable, but shows a general decrease with depth. There is also a covariance of the $\mathrm{Mn}$ and $\mathrm{Ni}$ contents.

Cores 2 through 6 show low values of $\mathrm{Ti}, \mathrm{Cr}$, and $\mathrm{V}$, in most cases less than half of the amounts elsewhere in the section.

The X-ray diffraction results indicate that Cores 1 through 6 (Unit 1 described above) have a distinctive composition from Unit 2 below. Specifically, quartz:plagioclase:illite ratios are $1: 1: 1$, and combined, these constituents make up only about $30 \%$ of the bulk fraction. Montmorillonite ranges from 10\% to $40 \%$ (highest in Core 2). Phillipsite is abundant in Cores 1,2, and upper part of Core 3 , but cristobalite replaces it as the dominant component in the lower part of Core 3 and in Cores 4 and 6.

When comparing the X-ray data with the atomic absorption analysis from Unit 1 , the only feature of the former which might correlate with the much higher values of $\mathrm{Ti}, \mathrm{Cr}$, and $\mathrm{V}$ in Core 1 is the high phillipsite content 
TABLE 1

Results of Atomic Absorption Analyses on Leg 17 Samples

\begin{tabular}{llllll}
\hline & $\mathrm{Mn}$ & $\mathrm{Ti}$ & $\begin{array}{c}\mathrm{Ni} \\
(\mathrm{ppm})\end{array}$ & $\mathrm{Cr}$ & $\mathrm{V}$ \\
Sample & & & & \\
\hline
\end{tabular}

Site 164

$\begin{array}{lrrrrr}1-5,146-148 \mathrm{~cm} & 12500 & 4100 & 380 & 54 & 240 \\ 2-2,110-112 \mathrm{~cm} & 10500 & 2250 & 240 & 15 & 70 \\ 3-1,60-62 \mathrm{~cm} & 8700 & 2240 & 250 & 24 & \text { low } \\ 4-1,105-107 \mathrm{~cm} & 3400 & 890 & 125 & 15 & 40 \\ 5-\mathrm{CC} & 6000 & 1530 & 170 & 27 & 140 \\ 6-1,133-135 \mathrm{~cm} & 6300 & 3300 & 270 & 31 & 75 \\ 7-4,63-64 \mathrm{~cm} & 10100 & 4150 & 185 & 39 & 170 \\ 8-3,32-34 \mathrm{~cm} & 10000 & 5360 & 200 & 50 & 150 \\ 9-\mathrm{CC} & 6700 & 5080 & 200 & 29 & 130 \\ 10-3,46-48 \mathrm{~cm} & 6500 & 5120 & 144 & 52 & 150 \\ 11-2,56-58 \mathrm{~cm} & 790 & 4440 & 80 & 50 & 170 \\ 12-1,107-109 \mathrm{~cm} & 940 & 5050 & 115 & 63 & 105 \\ 13-1,75-77 \mathrm{~cm} & 1120 & 5360 & 120 & 63 & 180 \\ 14-1,32-34 \mathrm{~cm} & 780 & 5150 & 100 & 65 & 240 \\ 15-1,129-131 \mathrm{~cm} & 2600 & 5900 & 105 & 65 & 130 \\ 16-1,144-146 \mathrm{~cm} & 6700 & 5600 & 125 & 71 & 140 \\ 17-1,138-140 \mathrm{~cm} & 3400 & 4450 & 105 & 64 & 180 \\ 18-1,54-56 \mathrm{~cm} & 9000 & 5660 & 110 & 66 & 130 \\ 19-2,96-98 \mathrm{~cm} & 7900 & 3540 & 155 & 37 & 100 \\ 20-1,125-127 \mathrm{~cm} & 5700 & 6250 & 115 & 68 & 130 \\ 21-1,106-108 \mathrm{~cm} & 390 & 6400 & 145 & 78 & 190 \\ 22-\mathrm{CC} & 1500 & 2580 & 100 & 30 & 70\end{array}$

Site 168

$\begin{array}{lrrrrr}2-C C & 8100 & 2300 & 245 & 125 & 40 \\ 3-C C & 5900 & 2020 & 195 & 26 & 50 \\ 4-2,45-47 \mathrm{~cm} & 10400 & 2140 & 310 & 18 & \text { low } \\ 5-C C & 4900 & 1100 & 175 & 9 & 140\end{array}$

Site 169

$\begin{array}{lrrrrr}1-1,148-150 \mathrm{~cm} & 670 & 3360 & 45 & 27 & 85 \\ 2-\mathrm{CC} & 920 & 4300 & 48 & 22 & 60 \\ 4-1,146-148 \mathrm{~cm} & 990 & 6400 & 110 & 65 & 170\end{array}$

Site 170

$\begin{array}{llllll}2-2,1-3 \mathrm{~cm} & 16300 & 3160 & 280 & 31 & 140\end{array}$

$(50 \%)$. However, the general lithologic and X-ray diffraction characteristics of the Tertiary clays in Unit 1 are matched by the consistency of the low values of $\mathrm{Ti}, \mathrm{Cr}$, and $\mathrm{V}$ in Cores 2 through 6.

The Cretaceous brown clays from Core 7 down (Unit 2) show a change in their mineralogical composition based on the bulk X-ray data. Compared with Unit 1, the quartz content is twice as high; K-feldspar appears and is more common than plagioclase feldspar. The illite content is about the same or just slightly higher than in Unit 1. The major contrast in these older clays, however, is the predominance of palygorskite, usually $30 \%$ to $60 \%$ and the reduction of montmorillonite to low amounts $(<10 \%$ or absent).

The quartz:total feldspar:illite ratio is about 1.5:1:1, and these three components combined are about equal to or slightly lower than the palygorskite content.

Phillipsite is not found in Unit 2, but small amounts of clinoptilolite are consistently present. Varying amounts of cristobalite are related to the presence of chert in parts of the clay sequence.

The $\mathrm{Ti}, \mathrm{Cr}$, and $\mathrm{V}$ contents in Unit 2 clays are usually more than double those of Unit 1. Both Ti and $\mathrm{Cr}$ show a general increase with depth. Thus, the AA results also illustrate the contrast between the composition of the Tertiary and Cretaceous clays. By examining Table 1 it can be seen that two samples (Cores 19 and 22) had Ti, Cr, and $\mathrm{V}$ values which were much lower than the remainder from Unit 2. Unfortunately, no samples from these cores were submitted for routine X-ray diffraction to the DSDP laboratory.

The abundance of palygorskite and almost total absence of montmorillonite in the Cretaceous clays (Unit 2) are significant. Palygorskite is a hydrated magnesium-rich silicate formed under conditions of excess silica and magnesium. The palygorskite at Site 164 does not progressively increase towards the base of the hole and therefore its origin must be authigenic and not hydrothermal. It is possible that the formation of palygorskite here, whether directly or with montmorillonite as an intermediate stage, is related to excess silica released by the dissolution of siliceous fossils in the Cretaceous clays. The Tertiary clays of Unit 2 above do contain abundant siliceous fossils. The silica released from this dissolution would then be available to combine with magnesium to form palygorskite. An alternative source of silica might be volcanic material and palagonite, and the shipboard party did notice the presence of the latter throughout the Tertiary clays though only in small amounts (see Site Report).

In some instances (e.g., Core 17) a low content (11\%) of palygorskite coincides with a high cristobalite content (57\%). Perhaps here, then, special local conditions have caused most of the excess silica to form chert rather than palygorskite.

One sample from Core 21 did not contain any palygorskite, but consisted mostly of clinoptilolite (44\%) and montmorillonite $(30 \%)$. This shows, therefore, that the conditions necessary for the formation of montmorillonite, palygorskite, and/or zeolites are still far from clear.

\section{Site 168}

This site is situated at $10^{\circ} 42.2^{\prime} \mathrm{N}, 173^{\circ} 35.9^{\prime} \mathrm{E}$ in a water depth of 5,420 meters. The brown clay section penetrated here is at least 66 meters thick and ranges in age from early Miocene (Core 2) through late Eocene (Cores 3,4) to late Middle Eocene (Core 5). Cores 2 and 3 were described as zeolitic brown clay and radiolarian ooze and Cores 4 and 5 as interbedded chert and radiolarian- and nannofossilbearing zeolitic clay (see Site Report). Four samples from Cores 2 through 5 were taken for AA analysis (Table 1), but X-ray data are only available from Core 4 . The limited data show that the brown clay of Miocene and Eocene age at Site 168 has a similar composition to the Oligocene and Eocene clay at Site 164 (Cores 2 through 6 of Unit 1). The $\mathrm{Ti}, \mathrm{Cr}$, and $\mathrm{V}$ contents are mostly low, $\mathrm{Mn}$ and $\mathrm{Ni}$ are moderately common and covary with each other. The quartz:plagioclase:illite:montmorillonite ratio is 1:1:1:2. Phillipsite is common (24\%). X-ray analyses by this author 
show that phillipsite is also abundant in Core 2 and common in Core 3. Some clinoptilolite occurs in Cores 3, 4, and 5 .

\section{Site 169}

This site is situated at $10^{\circ} 40.2^{\prime} \mathrm{N}, 173^{\circ} 33.0^{\prime} \mathrm{E}$ in a water depth of 5,407 meters. The brown clay section consists of zeolitic claystone and chert between 103 and 201 meters. Core 1 at 103 meters is Late Maastrichtian in age. Cores 2 and 4 were barren, but Core 3 is of Campanian age. The complete clay section is therefore Upper Cretaceous (see Site Report). Samples for AA analysis were taken from Cores 1, 2, and 4, and X-ray diffraction data are available from Cores 2, 6, and 7 .

The $\mathrm{Mn}$ and $\mathrm{Ni}$ contents from all three cores are very low here compared with Sites 164 and 168. The Ti, Cr, and $\mathrm{V}$ contents all indicate a difference in the composition between the clay in Cores 1 and 2 and that in Core 4, being low in the former and about twice as high in the latter.

Core 2 is the only one with complete X-ray data which can be compared with the AA results. Clinoptilolite is most abundant (40\%); cristobalite and palygorskite are less common $(<20 \%)$; and small amounts of quartz, K-feldspar, illite, and montmorillonite $(<10 \%)$ were also present. X-ray data of the older clays show that montmorillonite (Core 6) or palygorskite (Core 7) become dominant $(>50 \%)$.

\section{Site 170}

This site is situated at $11^{\circ} 48.0^{\prime} \mathrm{N}, 177^{\circ} 37.0^{\prime} \mathrm{E}$ in a water depth of 5792 meters. Twenty meters of Oligocene to Quaternary brown radiolarian zeolitic ooze and clay were penetrated. Atomic absorption and X-ray analyses are available from Core 2 of late Oligocene to early Miocene age.

The Mn and Ni contents are fairly high and the $\mathrm{Ti}$ and $\mathrm{Cr}$ contents low (Table 1). The X-ray data indicate a predominance of phillipsite $(68 \%)$ with much smaller amounts $(<15 \%)$ of palygorskite, montmorillonite, and quartz only.

\section{CONCLUSIONS}

Bearing in mind the limited amount of material and analyses available in this study, the following conclusions are tentatively proposed.

1) The Tertiary clays recovered from Leg 17 (Sites 164, $168,170)$ in the central Pacific are characterized by low contents of Ti and Cr, and in most cases, V also. In Site 169 these features of the trace element distribution also occur in the topmost part of the Cretaceous clay sequence. The $\mathrm{Mn}$ and $\mathrm{Ni}$ contents are generally higher in the Tertiary clays.

2) The Cretaceous clays are characterized by higher contents of $\mathrm{Ti}, \mathrm{Cr}$, and $\mathrm{V}$ and mostly lower $\mathrm{Mn}$ and $\mathrm{Ni}$ values than in the Tertiary.

3) X-ray diffraction results support the distinction in trace element composition between Tertiary and Cretaceous clays. The Tertiary clays show a marked predominance of phillipsite over clinoptilolite and smaller amounts of quartz:plagioclase feldspar:illite:montmorillonite in approximate ratios of $1: 1: 1: 2$.

4) The Cretaceous clays contain an abundance of palygorskite, or in a few cases montmorillonite, moderate amounts of clinoptilolite, but no phillipsite. K-feldspar is consistently present, plagioclase feldspar is either lacking or subordinate, and the quartz content is also higher.

5) Because an excess of $\mathrm{Ti}$ and $\mathrm{Cr}$ in sediments is considered indicative of a basic volcanic source, the higher values of these trace elements in the Cretaceous clays may indicate that a greater proportion of these sediments has been derived from such a source.

6) The quartz:feldspar:illite ratios (both in the bulk $\mathrm{X}$-ray samples and $2-20 \mu$ fraction) do not indicate a significant eolian contribution at any time. Presumably, then, most of the continentally derived materials in the brown clays in this region of the central Pacific have been transported to their site of deposition by submarine currents.

\section{ACKNOWLEDGMENTS}

The author thanks E. L. Winterer and J. Ewing, cruise co-chief scientists for Leg 17, for making samples available.

The atomic absorption analyses were made in the Scripps Institution of Oceanography analytical facility by D. Iddings under the supervision of $\mathbf{R}$. Laborde. Their careful work and assistance are greatly appreciated.

\section{REFERENCES}

Pimm, A. C., Garrison, R. E., and Boyce, R.E., 1971. Sedimentology synthesis: Lithology, chemistry and physical properties of sediments in the northwestern Pacific ocean: Initial Reports of the Deep Sea Drilling Project, Volume VI. Washington (U.S. Government Printing Office), p. 1131. 